\title{
The phrA gene of Rhodobacter sphaeroides encodes a photolyase and is regulated by singlet oxygen and peroxide in a $\sigma^{\mathrm{E}}$-dependent manner
}

\author{
Correspondence \\ Gabriele Klug \\ Gabriele.Klug@mikro.bio. \\ uni-giessen.de
}

Received 15 November 2006

Revised 1 February 2007

Accepted 5 February 2007

\author{
Anne-Kathrin Hendrischk, Stephan Braatsch, † Jens Glaeser \\ and Gabriele Klug
}

Institut für Mikrobiologie und Molekularbiologie, University of Giessen, Heinrich-Buff-Ring 26-32, D-35392 Giessen, Germany

\begin{abstract}
The genome of the facultatively photosynthetic bacterium Rhodobacter sphaeroides encodes three proteins of the photolyase/cryptochrome family. This paper shows that phrA (RSP2143) encodes a functional photolyase, which is an enzyme that repairs UV radiation-induced DNA damage in a blue light dependent manner. Expression of $p h r A$ is upregulated in response to light, with no photoreceptor or the photosynthetic electron transport being involved. The results reveal that singlet oxygen and hydrogen peroxide dependent signals are transmitted by the $\sigma^{\mathrm{E}}$ factor and the anti- $\sigma^{\mathrm{E}}$ factor $\mathrm{ChrR}$ affecting $p h r A$ expression, while superoxide anions do not stimulate phrA expression. Thus, the $\sigma^{\mathrm{E}}$ regulon is involved not only in the response to singlet oxygen but also in the hydrogen peroxide response.
\end{abstract}

\section{INTRODUCTION}

All organisms that are exposed to sunlight face the problem of UV light-induced DNA damage. The major UV products are cyclobutane pyrimidine dimers (CPDs), and to a lesser extent, pyrimidine-pyrimidone (6-4) photoproducts (reviewed by Sancar, 2003). Their accumulation blocks DNA replication and transcription and can therefore be lethal to cells. DNA photolyases repair these photoproducts in a blue/near-UV light dependent reaction referred to as photoreactivation (Rupert et al., 1958). Photolyases are closely related to cryptochromes, which belong to the same protein family (Cashmore et al., 1999).

Cryptochromes lack the ability for photoreactivation, but are instead known to function as blue light photoreceptors in diverse organisms by interacting with proteins such as COP1 and clock proteins (Yang et al., 2001; Lin \& Shalitin, 2003; Sancar, 2003). Plant cryptochromes mediate e.g. stem elongation and photoperiodic flowering in response to light (reviewed by Lin \& Shalitin, 2003). Cryptochromes in animals are light dependent and light independent regulators of the circadian clock (reviewed by Sancar, 2003). Almost all eukaryotic cryptochromes possess C-terminal domains beyond the photolyase-homology region while

tPresent address: Department of Microbiology and Immunology, University of British Columbia Life Sciences Centre, 4557-2350 Health Sciences Mall, Vancouver, BC V6T 1Z3, Canada.

Abbreviations: CPD, cyclobutane pyrimidine dimer; DASH, Drosophila, Arabidopsis, Synechocystis, Human; HDF, 8-hydroxy-7,8-didemethyl-5deazariboflavin. prokaryotic cryptochromes lack these C-terminal extensions (reviewed by Partch \& Sancar, 2005; Fig. 1). The recently identified cryptochrome Drosophila, Arabidopsis, Synechocystis, Human (cryptochrome DASH) proteins lack the C-terminal extension. This group was found to specifically repair CPDs in single-stranded DNA (Selby \& Sancar, 2006) and its members are therefore considered to be photolyases.

Proteins of the photolyase/cryptochrome family contain two noncovalently attached chromophores. The first, reduced FAD, is the catalytic cofactor in photoreactivation. The second cofactor, which serves as photoantenna, is either methenyltetrahydrofolate, 8-hydroxy-7,8-didemethyl-5-deazariboflavin (8-HDF), flavin mononucleotide (FMN) or FAD (reviewed by Sancar, 2003; Ueda et al., 2005; Fujihashi et al., 2007).

Anoxygenic photosynthetic proteobacteria of the genus Rhodobacter are metabolically extremely versatile. $R$. sphaeroides uses light for anoxygenic photosynthesis but can also perform aerobic or anaerobic respiration. As a free-living aquatic bacterium, $R$. sphaeroides is exposed to sunlight in its natural habitat (Page et al., 2004). However, solar radiation of high intensity is harmful due to the formation of DNA photoproducts. In the presence of oxygen and bacteriochlorophyll, it generates highly reactive singlet oxygen, which causes photooxidative damage (Borland et al., 1987). To minimize the risk of photooxidative damage, Rhodobacter has evolved complex regulatory circuits that control the expression of photosynthesis genes according to environmental conditions. Under high 


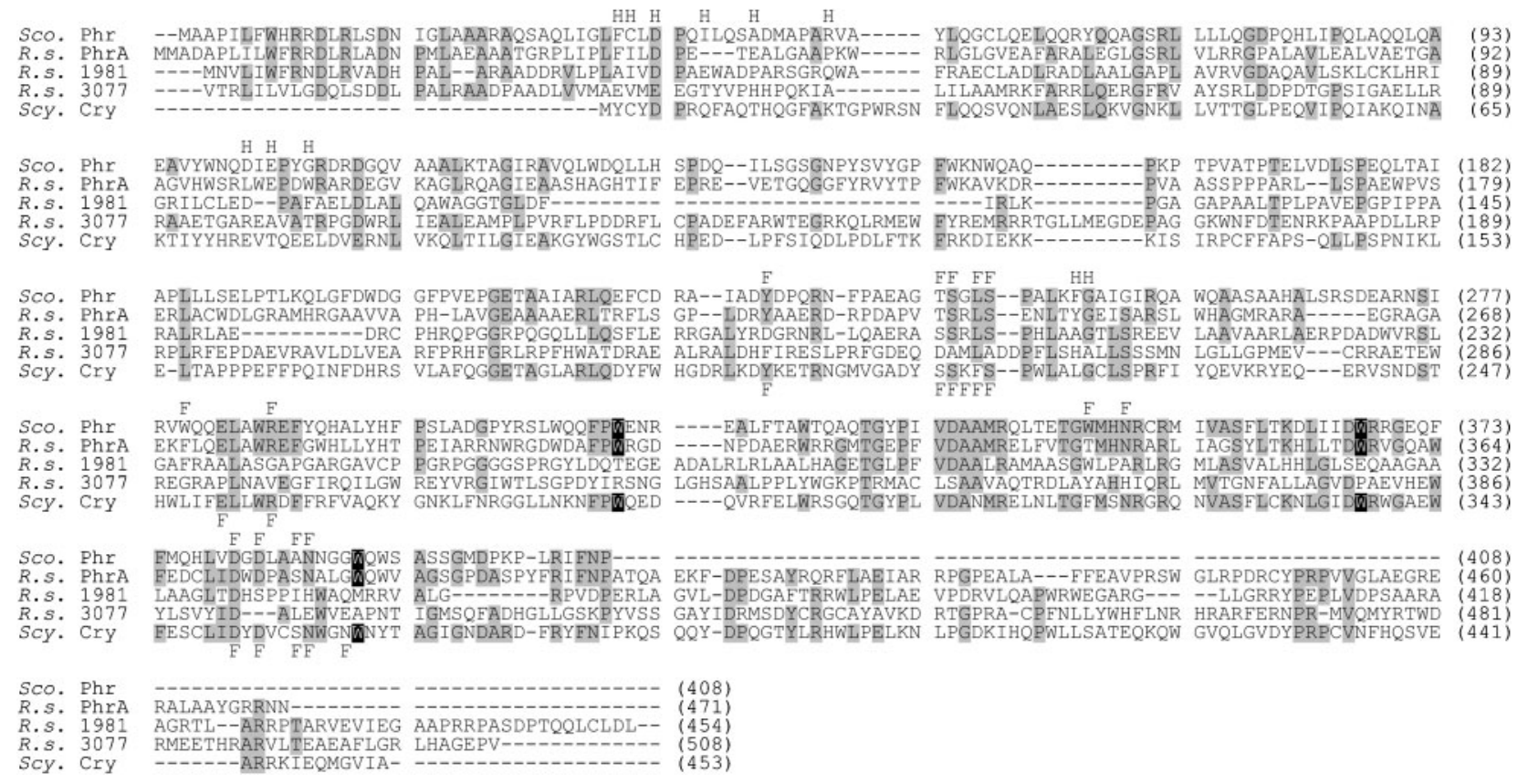

Fig. 1. Sequence alignment of proteins of the photolyase/cryptochrome family. Identical amino acids are boxed in grey. Amino acids which bind the cofactors FAD (F) and 8-HDF (H) are derived from the crystallographic structure of Synechococcus sp. 6301 (Tamada et al., 1997; top line) and Synechocystis sp. PCC6803 (Brudler et al., 2003; bottom line). The black boxed tryptophans are believed to be involved in intraprotein electron transport (Byrdin et al., 2003). The lengths of the proteins are indicated in parentheses. Sco. Phr, photolyase of Synechococcus sp. 6301 (Tamada et al., 1997); R.s. PhrA, photolyase of R. sphaeroides; R.s. 1981, RSP1981 gene product of R. sphaeroides; R.s. 3077, RSP3077 gene product of $R$. sphaeroides; Scy. Cry, cryptochrome DASH of Synechocystis sp. PCC6803 (Brudler et al., 2003). Comparison was carried out using MultAlin software (http://prodes.toulouse.inra.fr/multalin/multalin.html).

oxygen tension, in either the light or dark, the bacterium is virtually unpigmented and performs aerobic respiration. Only when the oxygen tension decreases is the photosynthetic apparatus formed (Zeilstra-Ryalls et al., 1998). When $R$. sphaeroides grows in the absence of oxygen by anaerobic respiration, light has a stimulating effect on the expression of photosynthesis genes (Braatsch et al., 2002). Recent investigations on the protection of $R$. sphaeroides against photooxidative stress showed the involvement of $\sigma^{\mathrm{E}}$ (RSP1092) and the anti- $\sigma^{\mathrm{E}}$ factor ChrR (RSP1093) in this response (Anthony et al., 2005; Glaeser \& Klug, 2005). $\sigma^{\mathrm{E}}$ is a member of the extracytoplasmatic function (ECF) family of $\sigma$ factors. ChrR belongs to a new family of zinccontaining anti- $\sigma$ factors (Newman et al., 2001) and inhibits the ability of $\sigma^{\mathrm{E}}$ to form a stable complex with core RNA polymerase by the formation of a $\sigma^{\mathrm{E}}$ : ChrR complex (Anthony et al., 2004).

The genome of $R$. sphaeroides encodes three proteins, the products of RSP1981, RSP2143 and RSP3077, with similarity to photolyases and cryptochromes. Here we show that RSP2143, putatively named phrA (Braatsch et al., 2004), encodes a functional photolyase. RSP3077 also seems to act as a photolyase, while RSP1981 has no function in photoreactivation. Furthermore, analysis of the expression of phrA under different growth conditions revealed its regulation by the $\sigma^{\mathrm{E}} / \mathrm{ChrR}$ system.

\section{METHODS}

Bacterial strains and growth conditions. All strains used in this study are listed in Table 1. Escherichia coli strains were cultured in Luria-Bertani broth at $37{ }^{\circ} \mathrm{C}$ with continuous shaking at 180 r.p.m. Rhodobacter sphaeroides strains were cultivated at $32{ }^{\circ} \mathrm{C}$ in a malate minimal salt medium (Drews, 1983) with continuous shaking at 140 r.p.m.

For semi-aerobic growth of $R$. sphaeroides strains, oxygen concentration in the culture flasks was $104 \pm 24 \mu \mathrm{M}$ throughout the experiment. Oxygen tension was monitored with a $\mathrm{Pt} / \mathrm{Ag}$ electrode (microoxygen sensor 501, UMS, Meiningen, Germany) and adjusted by varying the rotation speed of the shaker. Overnight grown cells were adapted to these conditions for one doubling time before illumination and experiments started when cultures had an $\mathrm{OD}_{660}$ of 0.2 . Blue light in semi-aerobically grown cultures was obtained by passing light from a $500 \mathrm{~W}$ halogen lamp or a high-pressure mercury-arc lamp (Schoeffel Instruments Co.) through a combination of heat-absorbing filter KG1 and filter BG12 (Schott). The maximum transmission of this filter is at $400 \mathrm{~nm}$ with a half-band width $\leqslant 80 \mathrm{~nm}$ and no detectable transmission at $<317$ or $>515 \mathrm{~nm}$. Photon flux density of each light quality measured at culture level was $10 \mu \mathrm{mol}$ photons $\mathrm{m}^{-2} \mathrm{~s}^{-1}\left(3 \mathrm{~W} \mathrm{~m}^{-2}\right)$ or at least $60 \mu \mathrm{mol}$ photons $\mathrm{m}^{-2} \mathrm{~s}^{-1}\left(60 \mathrm{~W} \mathrm{~m}^{-2}\right)$, respectively. 
Table 1. Bacterial strains and plasmids used in this study

\begin{tabular}{|c|c|c|}
\hline Strain/plasmid & Relevant characteristics ${ }^{*}$ & Source/reference \\
\hline \multicolumn{3}{|l|}{ E. coli } \\
\hline JM109 & Host strain for plasmid constructions & New England Biolabs \\
\hline MC1061 & Host strain for plasmid constructions, $\mathrm{Km}^{\mathrm{r}} \mathrm{Sm}^{\mathrm{r}}$ & Casadaban et al. (1980) \\
\hline S17-1 & Host strain for plasmid constructions, $\mathrm{Sp}^{\mathrm{r}}$ & Simon et al. (1983) \\
\hline HB101 & Host strain for pRK2013 & Ditta et al. (1985) \\
\hline \multicolumn{3}{|l|}{ R. sphaeroides } \\
\hline 2.4.1 & Wild-type & van Niel (1944) \\
\hline TF18 & rpoEchrR mutation in $2.4 .1, \mathrm{Tp}^{\mathrm{r}}$ & Schilke \& Donohue (1995) \\
\hline$\Delta \mathrm{ChrR}$ & chrR mutation in $2.4 .1, \mathrm{Tp}^{\mathrm{r}}$ & Newman et al. (1999) \\
\hline TC67 & Tn5 insertion into crtI, $\mathrm{Km}^{\mathrm{r}}$ & Lang et al. (1995) \\
\hline PUHA1 & puhA mutation in $2.4 .1, \mathrm{Km}^{\mathrm{r}}$ & Sockett et al. (1989) \\
\hline$\Delta p h r A$ & 2.4.1 with disruption of $p h r A, \mathrm{Km}^{\mathrm{r}}$ & This study \\
\hline$\Delta p h r A(\mathrm{pRK} p h r A)$ & Transconjugant of $\Delta p h r A$ with pRKphrA, $\mathrm{Km}^{\mathrm{r}} \mathrm{Tc}^{\mathrm{r}}$ & This study \\
\hline$\Delta 1981$ & 2.4.1 with disruption of RSP1981, $\mathrm{Km}^{\mathrm{r}}$ & This study \\
\hline$\Delta 3077$ & 2.4.1 with disruption of RSP3077, $\mathrm{Km}^{\mathrm{r}}$ & This study \\
\hline 2.4.1 (pPHUphrAlacZ) & 2.4.1 harbouring pPHUphrAlacZ & This study \\
\hline TF18 (pPHUphrAlacZ) & TF18 harbouring pPHUphrAlacZ & This study \\
\hline$\Delta \mathrm{ChrR}(\mathrm{pPHU}$ phrAlacZ) & $\Delta$ ChrR harbouring pPHUphrAlacZ & This study \\
\hline TC67 (pPHUphrAlacZ) & TC67 harbouring pPHUphrAlacZ & This study \\
\hline PUHA1(pPHUphrAlacZ) & PUHA1 harbouring pPHUphrAlacZ & This study \\
\hline \multicolumn{3}{|l|}{ Plasmids } \\
\hline pPHU281 & Suicide vector for Rhodobacter, $\mathrm{Tc}^{\mathrm{r}}$ & Hübner et al. (1993) \\
\hline pUC4K & Vector containing $\mathrm{Km}$ cassette & Vieira \& Messing (1982) \\
\hline pRK415 & Shuttle vector for expression in Rhodobacter, $\mathrm{Tc}^{\mathrm{r}}$ & Keen et al. (1988) \\
\hline pRK2013 & Mobilizing vector, $\mathrm{Km}^{\mathrm{r}}$ & Ditta et al. (1985) \\
\hline pPHU234 & Vector with promoterless $l a c Z$ coding region, $\mathrm{Tc}^{\mathrm{r}}$ & Hübner et al. (1991) \\
\hline pPHU $\Delta p h r A$ & $\begin{array}{l}\text { pPHU } 281 \text { with Km cassette, flanked by phrA up- and downstream } \\
\text { region }\end{array}$ & This study \\
\hline pPHU $\Delta 1981$ & $\begin{array}{l}\text { pPHU281 with Km cassette, flanked by RSP1981 up- and } \\
\text { downstream region }\end{array}$ & This study \\
\hline pPHU $\Delta 3077$ & $\begin{array}{l}\text { pPHU281 with Km cassette, flanked by RSP3077 up- and } \\
\text { downstream region }\end{array}$ & This study \\
\hline $\mathrm{pRK} p h r A$ & pRK415 harbouring $p h r A$ coding region, $\mathrm{Tc}^{\mathrm{r}}$ & This study \\
\hline pRK3077 & pRK415 harbouring RSP3077 coding region, $\mathrm{Tc}^{\mathrm{r}}$ & This study \\
\hline pPHUphrAlacZ & pPHU234 with phrA upstream-region, $\mathrm{Tc}^{\mathrm{r}}$ & This study \\
\hline
\end{tabular}

${ }^{\star} \mathrm{Km}^{\mathrm{r}}$, kanamycin resistant; $\mathrm{Sm}^{\mathrm{r}}$, streptomycin resistant; $\mathrm{Sp}^{\mathrm{r}}$, spectinomycin resistant; $\mathrm{Tc}^{\mathrm{r}}$, tetracycline resistant; $\mathrm{Tp}^{\mathrm{r}}$, trimethoprim resistant.

For aerobic growth, overnight cultures with an $\mathrm{OD}_{660}$ of 0.2 were transferred to a flask and gassed with air, resulting in an oxygen concentration of approximately $180 \mu \mathrm{M}$. To test for the effect of illumination, cultures grown under dark aerobic conditions to an $\mathrm{OD}_{660}$ of 0.4 were illuminated with a $500 \mathrm{~W}$ halogen lamp with a light intensity of $800 \mathrm{~W} \mathrm{~m}^{-2}\left(750 \mu \mathrm{mol}\right.$ photons $\mathrm{m}^{-2} \mathrm{~s}^{-1}$; high intensity white light), or $800 \mathrm{~W} \mathrm{~m}^{-2}\left(380 \mu \mathrm{mol} \mathrm{m} \mathrm{m}^{-2} \mathrm{~s}^{-1}\right.$; high intensity red light) or $30 \mathrm{~W} \mathrm{~m}^{-2}\left(18 \mu \mathrm{mol}\right.$ photons $\mathrm{m}^{-2} \mathrm{~s}^{-1}$; low intensity white light). A filter transmitting wavelength greater $600 \mathrm{~nm}$ was used for red light illuminations. Light energy in $\mathrm{W} \mathrm{m}^{-2}$ was measured with a LI-250 light metre equipped with a LI-200SA pyranometer sensor (spectral response of 400-1100 nm, LI-Cor) and photon flux in $\mu \mathrm{mol}$ photons $\mathrm{m}^{-2} \mathrm{~s}^{-1}$ was measured with an LI-189 light metre equipped with a LI-190SA quantum sensor (spectral response of 400-700 nm, LI-Cor).

When required, antibiotics were used at the following concentrations: kanamycin $25 \mu \mathrm{g} \mathrm{ml}^{-1}$; tetracycline $20 \mu \mathrm{g} \mathrm{ml}^{-1}$ (E. coli) or $2 \mu \mathrm{g} \mathrm{ml}^{-1}$ (R. sphaeroides); trimethoprim $50 \mu \mathrm{g} \mathrm{m} l^{-1}$ (R. sphaeroides). In the presence of light, no tetracycline was added. For the generation of singlet oxygen, methylene blue (Sigma-Aldrich) was added to a final concentration of $0.2 \mu \mathrm{M}$. To test the effect of hydrogen peroxide $\left(\mathrm{H}_{2} \mathrm{O}_{2}\right)$ and superoxide anions on phrA expression, $\mathrm{H}_{2} \mathrm{O}_{2}$ and paraquat were added to a final concentration of $1 \mathrm{mM}$ to $R$. sphaeroides cultures with an $\mathrm{OD}_{660}$ of 0.5 .

Photoreactivation activity. Overnight cultures of Rhodobacter strains grown to an $\mathrm{OD}_{660}$ of 0.8 were diluted $1: 100$ in malate minimal salt medium. After exposure to various doses of UV light at $254 \mathrm{~nm}$ (UVcross-linker 1800, Stratagene), the cells were plated on agar plates in a dark room with dim red light, and afterwards exposed to the light of a $58 \mathrm{~W}$ fluorescent lamp (TLD 58W/25, Philips). For photoreactivation, the plates were covered with the plastic cover of the Petri dish. Photon flux density measured at culture level was 35-40 $\mu$ mol photons $\mathrm{m}^{-2} \mathrm{~s}^{-1}$ (LI-190SA quantum Sensor, LI-Cor; spectral response 400$700 \mathrm{~nm}$ ). Control plates were wrapped in aluminium foil for growth in the dark. After 3 days, the colonies were counted and survivals relative to UV-unirradiated controls were calculated. 
Genetic techniques. DNA cloning was performed according to standard protocols (Sambrook \& Russell, 2001). All plasmids used are listed in Table 1. Oligonucleotides generating suitable recognition sites for cloning or used as primers for RT-PCR analyses were synthesized by Roth. DNA sequencing was performed with an ABIPrism 310 genetic analyser (Applied Biosystems).

Construction of $R$. sphaeroides $\Delta$ phrA, $\Delta 1981$ and $\Delta 3077 . R$. sphaeroides $\Delta p h r A, \Delta 1981$ and $\Delta 3077$ were generated by transferring plasmid pPHU $\Delta$ phrA, pPHU $\Delta 1981$ or pPHU $\Delta 3077$ into $R$. sphaeroides. Fragments $(500 \mathrm{bp})$ of the $5^{\prime}$ and $3^{\prime}$ ends of the genes were amplified by PCR using the oligonucleotides phrAHindIII $u p$ (5'-GGGAAGCTTCAGGCCGATCTCCCCCC-3'), phrAEcoRI up (5' GGAATTCGAAGATCGTATGGCCC-3'), phrAEcoRIdown (5'GAATTCGTGACCGGCACCATG-3') and phrAXbaIdown (5'-GCTCTAGAGCCGTCATTCGTGTCC-3') for $p h r A ; 1981$ HindIII $u p$ (5'-GGGAAGCTTCGCGACCTGCCTCG-3'), 1981ScaI up (5' -CCGGCCCAGTACTGCAGG-3'), 1981ScaIdown (5'-GTGGATGCAGTACTGCGCG-3') and 1981XbaIdown (5'-CGTCTAGAAACATGACCAATCCGCC-3') for RSP1981 and 3077HindIII $u p$ (5'-CCCAAGCTTGGGCTCGACTGGAGCCGA-3'), 3077ScaI up (5'-AAAAGTACTTTTCGATCAGCCGCCAGTC-3' ${ }^{\prime}, \quad$ 3077ScaIdown $\quad\left(5^{\prime}\right.$ AAAAGTACTTTTCGCGCTGCTGGCGGG-3') and 3077XbaIdown (5'-GCTCTAGAGCTTCCGCCTCGGTCAGA-3') for RSP3077. The $\mathrm{Km}^{\mathrm{r}}$ gene (Vieira \& Messing, 1982), flanked by the corresponding fragments, was inserted in the suicide plasmid pPHU281 (Hübner et al., 1993). The plasmids were transferred into E. coli S17-1 and each was then transferred into $R$. sphaeroides 2.4 .1 by biparental conjugation. Southern blotting was performed of kanamycin-resistant, tetracyclinesensitive clones, to confirm that the target genes had been replaced by the inactive gene through double crossover.

Complementation of $R$. sphaeoides $\Delta p h r A$ and $\Delta 3077$. For complementation of $R$. sphaeroides $\Delta p h r A$ or $\Delta 3077$, the genes $p h r A$ or RSP3077 with around $100 \mathrm{bp}$ of the flanking sequences on each end were generated with primers phrAHindIII $u p$ and phrAXbaIdown or $3077 \mathrm{HindIII} u p$ and $3077 \mathrm{XbaI}$ down, respectively. The fragments were ligated into plasmid pRK415, and the resulting plasmids pRKphrA and pRK3077 were transferred into the recipient strain by triparental mating as described earlier (Klug \& Drews, 1984).

Construction of the phrA : lacZ reporter plasmid. The putative promoter region of phrA $(-108$ to $+130 \mathrm{bp})$ was amplified with the oligonucleotides phrAlacZup (5'-GCGAATTCAGGCCGATCTCCCCC-3') and phrAlacZdown (5'-CGGTCTCGGGATCCAGAATGAAC$\left.3^{\prime}\right)$ and ligated in the vector pPHU234, carrying the promoterless lac $Z$ gene. The construct was conjugated into $R$. sphaeroides strains, as well as the plasmid pPHU234, as a control.

$\boldsymbol{\beta}$-Galactosidase assay. This was carried out as described previously (Hübner et al., 1991).

RNA extraction and real-time RT-PCR. Total RNA of $R$. sphaeroides cells grown under different conditions was isolated as described previously (Nieuwlandt et al., 1995) and quantified by spectrophotometric analysis (absorbance at $260 \mathrm{~nm}$ ). For quantitative real-time RT-PCR, $40 \mathrm{ng}$ total RNA was used and the One-Step RTPCR kit (Qiagen) and Reverse-iT One-Step RT-PCR Kit (ABgene), following the manufacturer's instructions. The amplification of PCR products [oligonucleotides phrA-A (5'-GTTCGAGGACTGCCTGAT$\left.3^{\prime}\right)$ and phrA-B (5'-AGGAACCTCTGGCGATAG-3') for $p h r A$, lacZA (5'-CATTCAGGCTGCGCAACT- $\left.3^{\prime}\right)$ and lacZ-B (5' ${ }^{\prime}$-TTAATCGCCTTGCAGCAC-3') for lac $Z$ and rpoZ-A ( $5^{\prime}$-ATCGCGGAAGCCAGAG-3') and rpoZ-B ( $5^{\prime}$-GAGCAGCGCCGATCCT-3') for rpoZ] was monitored with SYBR Green using a Rotor-Gene 3000 real-time PCR cycler (LTF). Relative expression of $p h r A$ and $r p o Z$ (a housekeeping $\sigma$-factor) mRNA were calculated by the method of Pfaffl (2001).

\section{RESULTS AND DISCUSSION}

\section{R. sphaeroides harbours three members of the photolyase/cryptochrome family}

The R. sphaeroides 2.4.1 genome sequence (http://mmg. uth.tmc.edu/sphaeroides/) contains three ORFs (phrA, RSP1981 and RSP3077) encoding proteins with similarity to photolyase/cryptochrome proteins. According to DNA microarray studies, all three genes are transcribed (our unpublished microarray chip data). We recently identified and characterized a CPD-photolyase from the related organism Rhodobacter capsulatus (Braatsch \& Klug, 2004). In contrast to $R$. sphaeroides this protein appears to be the only member of the photolyase/cryptochrome family in this organism. PhrA, RSP1981 and RSP3077 exhibit $61 \%$, $31 \%$ and $24 \%$ sequence identity, respectively, to the protein encoded by ORF90. Primary sequence comparison with the CPD-photolyase derived from Synechococcus sp. 6301 (Tamada et al., 1997) revealed several conserved residues shown to be involved in cofactor binding (Tamada et al., 1997; Fig. 1). Photolyases provide three conserved tryptophan residues, which were supposed to be involved in electron transport to reduce the $\mathrm{FADH}_{2}$ (Byrdin et al., 2003, Fig. 1). These residues are present in PhrA, but are notably absent in RSP1981 and RSP3077. However, since blocking photoreduction through this tryptophan chain by point mutations has little or no physiological significance for the in vivo activity of the E. coli photolyase (Kavakli \& Sancar, 2004), the absence of the tryptophan triad does not necessarily correlate with a loss of photolyase function in RSP1981 and RSP3077.

\section{phrA and RSP3077, but not RSP1981, are responsible for photoreactivation in $R$. sphaeroides}

A quantitative analysis of UV light challenge revealed that $R$. sphaeroides 2.4.1 indeed shows photoreactivation (Fig. 2). While only $8 \%$ of $R$. sphaeroides wild-type cells survived $100 \mathrm{~J} \mathrm{~m}^{-2} \mathrm{UV}$ light exposure without photoreactivation, subsequent illumination increased the survival rate by a factor of 6.6 to $53 \%$. To test for a photolyase function, the gene phrA, RSP1981 or RSP3077 was inactivated by insertion of a kanamycin resistance cassette, and the resulting mutants were tested for photoreactivation. All mutants showed a comparable survival after UV light as the wild-type when light was not available (Fig. 2). When R. sphaeroides $\Delta p h r A$ was illuminated after exposure to UV light, we observed a significantly decreased survival rate $(3 \%)$ in comparison to the wild-type ( $53 \%$, Fig. 2 ). Complementation of $R$. sphaeroides $\Delta p h r A$ by plasmidborne phrA restored photoreactivation properties and increased the survival rate of the deletion mutant 14 -fold. 


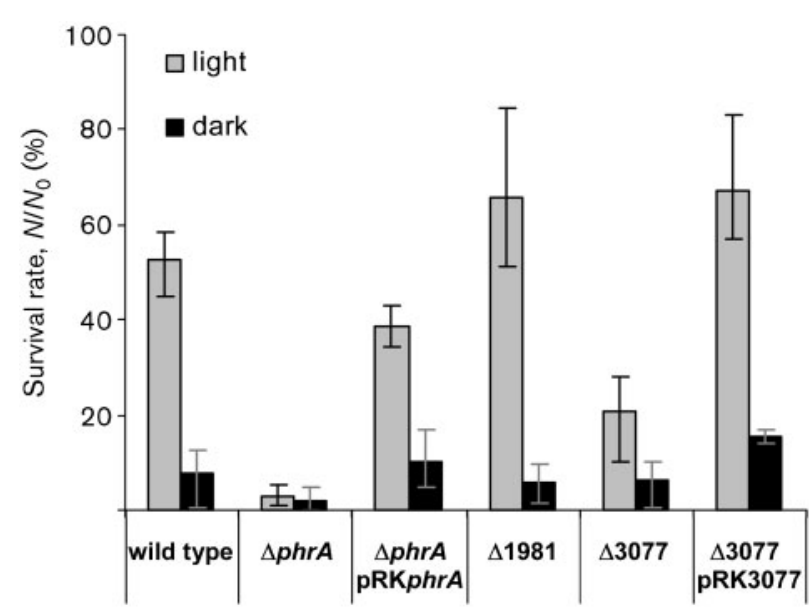

Fig. 2. Survival of $R$. sphaeroides after UV light exposure. Cells of the indicated strains were exposed to UV light of $100 \mathrm{~J} \mathrm{~m}^{-2}$ (254 $\mathrm{nm}$ ), spread on agar plates and kept in the light (58 W lamp) or in the dark. The survival rates are given as the mean of three experiments with maximal deviation.

The complementation of the photolyase mutant by the phrA gene is a clear proof for its function as photolyase.

Mutation of RSP1981 leads to no significant difference in survival compared to the wild-type, except a slightly increased survival (66\%) after UV light exposure and subsequent illumination. This gene is obviously not involved in photorepair.

R. sphaeroides lacking RSP3077 showed photoreactivation; survival increased about 3.5-fold after illumination. Interestingly, the RSP3077 mutant showed 2.5-fold reduced survival $(21 \%)$ in comparison to the wild-type (53\%). When this strain was complemented, illumination increased the survival to $67 \%$, similar to that of the complemented phrA mutant. Selby \& Sancar (2006) reported recently that members of the previously found cryptochrome DASH family (Brudler et al., 2003; Daiyasu et al., 2004) repair single stranded DNA. Although RSP3077 shows only minor (up to $9 \%$ ) sequence identity to members of this family, we can not exclude a function of RSP3077 in this regard and a role as putative second photolyase.

\section{Expression of phrA is regulated by $\sigma^{\mathrm{E}}$ and the anti- $\sigma^{\mathrm{E}}$ factor ChrR}

To date, there has been no evidence of a specific regulatory mechanism for the photolyase gene in any organism studied in this regard. Previous analysis of the promoter region of $p h r A$ revealed the presence of a putative $\sigma^{\mathrm{E}}$ DNAbinding site, which is identical to the rpoE consensus sequence (Braatsch et al., 2004). Additional transcriptome analysis and in vitro transcription studies support the view that phrA is under control of $\sigma^{\mathrm{E}}$ (Anthony et al., 2005).
In order to confirm these data and to test for the involvement of the anti- $\sigma^{\mathrm{E}}$ factor ChrR, we compared the expression level of phrA in the wild-type strain $R$. sphaeroides 2.4 .1 and in the derived mutant strains TF18 and $\Delta$ ChrR grown at high oxygen tension in the dark. Mutant strain TF18 has the rpoE and the chrR genes deleted (Schilke \& Donohue, 1995), while mutant strain $\Delta \mathrm{ChrR}$ has only chrR inactivated (Newman et al., 1999). When a phrA : lacZ reporter plasmid (pPHUphrAlacZ) was introduced into the wild-type strain, we observed a low $\beta$ galactosidase activity of 6 Miller units (Fig. 3a). In strain TF18, the activity was only 1 unit (Fig. 3a), which was the same as background (not shown). In contrast, we obtained about 200 Miller units in strain $\Delta$ ChrR harbouring the reporter plasmid (Fig. 3a). These data suggest that $\sigma^{\mathrm{E}}$ is required for transcription of $p h r A$ and that ChrR strongly counteracts $\sigma^{\mathrm{E}}$-mediated transcription, as was shown previously (Anthony et al., 2004).

The fact that the photolyase of the related $R$. capsulatus, encoded by ORF90, has $61 \%$ sequence identity to PhrA suggests the presence of a similar regulatory mechanism of this photolyase gene. Interestingly, analysis of the genome of $R$. capsulatus showed neither an ORF with high similarity to $\sigma^{\mathrm{E}}$ or to ChrR of $R$. sphaeroides, nor an $\sigma^{\mathrm{E}}$ like binding region in the promoter of ORF90.

\section{Upregulation of phrA expression depends on light intensity and can be enhanced by the photosensitizer methylene blue}

Although photolyase activity is only required upon the formation of pyrimidine dimers, phrA seems to be expressed even in the absence of light (Fig. 3a and our unpublished microarray chip data). However, we have reported before that blue light stimulates $p h r A$ expression (Braatsch et al., 2004). In the fungus Trichoderma harzianum (Berrocal-Tito et al., 1999) and in the goldfish Carassius auratus (Mitani et al., 1996; Mitani \& Shima, 1995; Yasuhira et al., 1991) blue light as well as $\mathrm{H}_{2} \mathrm{O}_{2}$ induces the transcription of the photolyase gene. Kihara et al. (2004) showed that near-UV light (300-400 nm) and sunlight enhance the expression of the photolyase in the fungus Bipolaris oryzae. Therefore, it is possible that phrA gene expression is upregulated in response to general stressors. To test this hypothesis, we used the phrA : lacZ reporter plasmid and performed real-time RT-PCR to monitor $\sigma^{\mathrm{E}} / \mathrm{ChrR}$ dependent phrA expression in cultures grown under different light conditions. We used methylene blue as a photosensitizer to generate singlet oxygen in irradiated cultures and tested whether phrA may also respond to other reactive oxygen species, i.e. $\mathrm{H}_{2} \mathrm{O}_{2}$ or superoxide anions, in a $\sigma^{\mathrm{E}} / \mathrm{ChrR}$ dependent manner.

R. sphaeroides 2.4.1 and mutant strains TF18 and $\Delta \mathrm{ChrR}$ carrying the reporter plasmid pPHUphrAlacZ were grown in the dark under high oxygen concentration and then shifted to high intensity white light $\left(800 \mathrm{~W} \mathrm{~m}^{-2}\right.$ or $750 \mu \mathrm{mol}$ photons $\mathrm{m}^{-2} \mathrm{~s}^{-1}$ ) in the presence or absence of 

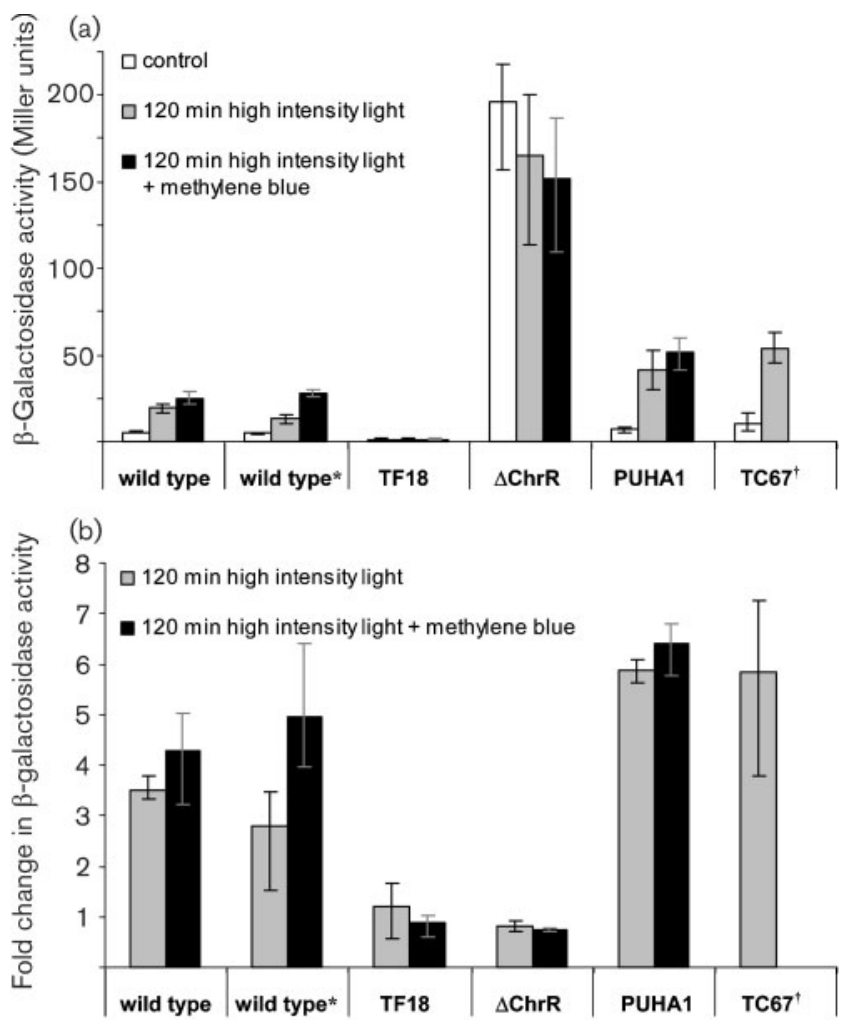

(c)

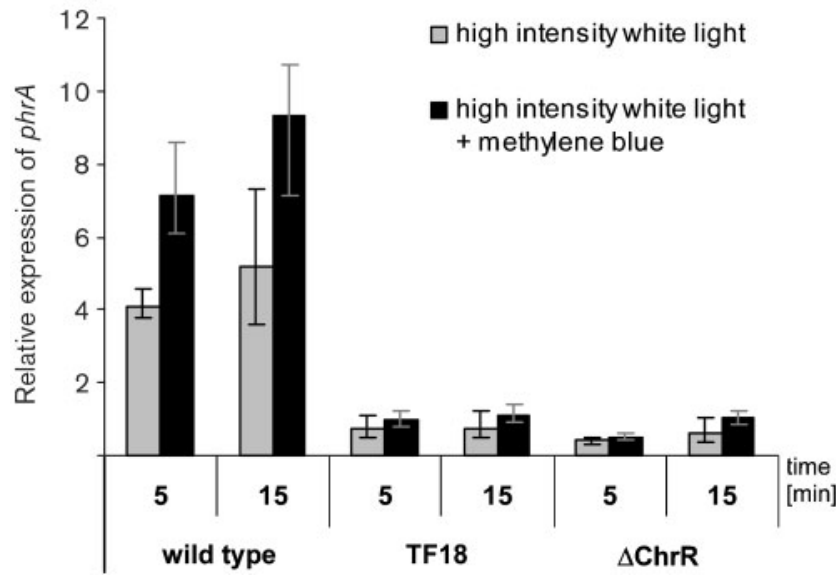

Fig. 3. Expression of $p h r A$ in response to high intensity light irradiation and methylene blue treatment. Cells grown aerobically in the dark to an $\mathrm{OD}_{660}$ of 0.4 were exposed to high intensity light irradiation and treated simultaneously with $0.2 \mu \mathrm{M}$ methylene blue where indicated. The data represent the mean of three independent experiments. Error bars indicate maximal deviation. (a) $\beta$ Galactosidase activity of strains harbouring a $p h r A$ : lacZ reporter plasmid. The cells were exposed to high intensity white light irradiation for $120 \mathrm{~min}$. *This wild-type strain was illuminated with high intensity red light. †Strain TC67 was exposed to low intensity white light irradiation. (b) The same assay as (a) but showing the fold changes of $\beta$-galactosidase activity. (c) phrA expression levels normalized to dark-grown cells as determined by real-time RTPCR. Cultures were exposed to high intensity white light irradiation for 5 or $15 \mathrm{~min}$, as indicated. methylene blue. In all strains tested the addition of $0.2 \mu \mathrm{M}$ methylene blue in the dark did not affect the $\beta$ galactosidase activity (data not shown). In the wild-type, the $\beta$-galactosidase activity increased from 5.5 to 19 Miller units after 120 min of white light illumination (Fig. 3a, b). An identical light shift experiment in the presence of methylene blue resulted in a slightly increased $\beta$-galactosidase activity ( 25 Miller units, Fig. $3 a, b)$. No such light dependent increase in activity was observed in strains TF18 or $\Delta$ ChrR (Fig. 3a, b). Here, methylene blue did not affect the $\beta$-galactosidase activity of the illuminated mutant strains (Fig. 3a, b).

To confirm the reporter gene studies, we used real-time RT-PCR for determination of the relative increase in phrA levels due to illumination in the presence or absence of methylene blue (Fig. 3c). For the wild-type, we observed a relative fourfold upregulation in $p h r A$ expression as early as $5 \mathrm{~min}$ of irradiation. A prolonged illumination of $15 \mathrm{~min}$ resulted in a fivefold increase in phrA transcript level compared to the dark aerobic control. No such significant upregulation was observed for the mutant strains TF18 and ChrR, which is in line with our reporter gene studies (Fig. 3a, b). Interestingly, illumination of wild-type cultures in the presence of methylene blue caused a further 1.8 -fold upregulation of $p h r A$ expression at the given time points while no effect of the photosensitizer was detectable for the mutant strains (Fig. 3c). The higher phrA transcript level observed in the wild-type cultures treated with the photosensitizer suggests that singlet oxygen is a trigger for this response. It is conceivable that the $\beta$-galactosidase activity is impaired by the presence of singlet oxygen. However, our results strongly suggest that (i) white light illumination triggers a phrA upregulation in aerobically grown $R$. sphaeroides cells and that (ii) the $\sigma^{\mathrm{E}} / \mathrm{ChrR}$ pathway is responsible for signal transduction, resulting in a fast transcriptional response.

When we illuminated semi-aerobically grown wild-type cells with blue light of $10 \mu \mathrm{mol}$ photons $\mathrm{m}^{-2} \mathrm{~s}^{-1}$ ( $3 \mathrm{~W} \mathrm{~m}^{-2}$ ), we did not see any significant change in $p h r A$ expression as determined by the $p h r A$ : lac $Z$ reporter plasmid or by real-time RT-PCR (not shown). This is not in agreement with previously published data (Braatsch et al., 2004), where a 3.9-fold increase in phrA expression was described after 5 min blue light illumination with 10 $\mu \mathrm{mol}$ photons $\mathrm{m}^{-2} \mathrm{~s}^{-1}$ of the wild-type. In the latter case light intensities were monitored with a lux metre (DX100 ), so it is conceivable that the light intensities used for the previous experiments were indeed higher than the 10 $\mu$ mol photons $\mathrm{m}^{-2} \mathrm{~s}^{-1}$ used in the experiments reported here and monitored by a quantum sensor (LI-190SA). Indeed, when we increased the intensity of blue light to 60 $\mu$ mol photons $\mathrm{m}^{-2} \mathrm{~s}^{-1}$, the $\beta$-galactosidase activity in wild-type cells increased twofold (not shown).

When wild-type cells were grown under high oxygen tension and illuminated with red light of high intensity $\left(800 \mathrm{~W} \mathrm{~m}^{-2}\right.$ or $380 \mu \mathrm{mol}$ photons $\mathrm{m}^{-2} \mathrm{~s}^{-1}$ ) we 
determined a 2.8 -fold increase in phrA expression by the reporter assay and a 4.8 -fold increase in the presence of methylene blue (Fig. 3a, b). Controls in the dark with or without methylene blue did not show any significant changes in $\beta$-galactosidase activity. These data reveal that phrA does not specifically respond to blue light and that no specific photoreceptor appears to be involved.

\section{phrA expression of $R$. sphaeroides 2.4 .1 responds to singlet oxygen}

The amplifying effect of methylene blue on $p h r A$ expression of illuminated cells (Fig. 3a-c) suggests that singlet oxygen is a trigger for this response. To further support this assumption, we monitored phrA expression in strain TC67, which lacks carotenoids. Carotenoids are essential constituents of the photosynthetic apparatus and are assumed to prevent the formation of singlet oxygen by quenching of triplet bacteriochlorophyll $a$ in vivo (Borland et al., 1989). It was shown previously that, in the presence of oxygen and high light, $R$. sphaeroides forms small amounts of singlet oxygen in vivo, which do not adversely affect cell growth (Glaeser \& Klug, 2005). Higher amounts of singlet oxygen were generated by bacteriochlorophyll $a$ in the carotenoiddeficient strain TC67, causing a decrease in growth and survival rates (Glaeser \& Klug, 2005). When strain TC67(pPHUphrAlacZ) was illuminated with white light of low intensity $\left(30 \mathrm{~W} \mathrm{~m}^{-2}\right.$ ), the $\beta$-galactosidase activity increased about fivefold within $2 \mathrm{~h}$ (Fig. 3a, b). The induction of a comparable response in the wild-type required a 26 -fold higher light intensity $\left(800 \mathrm{~W} \mathrm{~m}^{-2}\right.$; Fig. 3a, b). The more light sensitive phrA upregulation in strain TC67 supports our view that singlet oxygen can trigger this response.

We also monitored phrA expression by using the reporter plasmid in strain PUHA1, which lacks the H-subunit of the reaction centre (RC). In the RC all the cofactors are bound to the $\mathrm{L}$ and $\mathrm{M}$ subunits. A RC complex in which the $\mathrm{H}$ peptide has been stripped away, leaving an LM remnant, retains full primary photoactivity. However, in these LM complexes, the $\mathrm{Q}_{\mathrm{A}}$ to $\mathrm{Q}_{\mathrm{B}}$ reaction is impaired and the complexes are significantly less stable than LMH (Debus et al., 1985). In vivo, reaction centres lacking the $\mathrm{H}$ subunit are virtually absent as determined by spectroscopy (Tehrani et al., 2003) and as a consequence, strain PUHA1 can not grow phototrophically. Illumination of PUHA1 by high white light intensity resulted in about sixfold increase of phrA expression, high light and methylene blue in about sevenfold increase (Fig. 3a, b). This is significantly higher than in the wild-type (3.5- and 4.2-fold, respectively), suggesting that the lack of RC may amplify the signal acting on phrA. Most likely, energy transfer from excited bacteriochlorophyll to oxygen is enhanced when no photosynthetic electron transport can be initiated in the RC. Furthermore, we conclude that photosynthetic electron transport is not involved in light dependent regulation of $p h r A$ expression, as demonstrated for the upregulation of photosynthesis genes (Happ et al., 2005).

\section{phrA expression of $R$. sphaeroides 2.4 .1 responds to hydrogen peroxide but not to superoxide anions}

In order to test whether $p h r A$ expression may also respond to other reactive oxygen species, we quantified its expression in the presence of $\mathrm{H}_{2} \mathrm{O}_{2}$ and the superoxidegenerating agent paraquat. By using the phrA : lac Z reporter plasmid we could not observe any significant expression changes in response to $\mathrm{H}_{2} \mathrm{O}_{2}$ (Fig. 5) or paraquat (not shown). However, we had observed before that the lac $Z$ gene is not suitable to monitor the response to $\mathrm{H}_{2} \mathrm{O}_{2}$ and superoxide anions (see below), presumably due to loss of activity of the $\beta$-galactosidase under oxidative stress.

Real-time RT-PCR analysis of phrA expression revealed a transient upregulation due to $\mathrm{H}_{2} \mathrm{O}_{2}$ exposure (Fig. 4). As soon as 7 min after $\mathrm{H}_{2} \mathrm{O}_{2}$ exposure, we observed a 5.6-fold increase in phrA transcript level (Fig. 4). In strains TF18 and $\Delta \mathrm{ChrR}$, which lack $\sigma^{\mathrm{E}}$ and ChrR or ChrR, respectively, the phrA activity dropped about twofold upon $7 \mathrm{~min}$ exposure to $\mathrm{H}_{2} \mathrm{O}_{2}$ (Fig. 4). However, after $30 \mathrm{~min}$ of $\mathrm{H}_{2} \mathrm{O}_{2}$ treatment a relative $\sim 1.5$-fold increase in phrA transcript levels was observed in all three strains (Fig. 4). Based on gene expression dynamics we conclude that the $\sigma^{\mathrm{E}} / \mathrm{ChrR}$ pathway is responsible for the fast upregulation of phrA. For unknown reasons, expression of this gene was found to be slightly downregulated in mutant strains TF18 and $\Delta$ ChrR after $7 \mathrm{~min}$ (Fig. 4 ). Since a prolonged exposure to

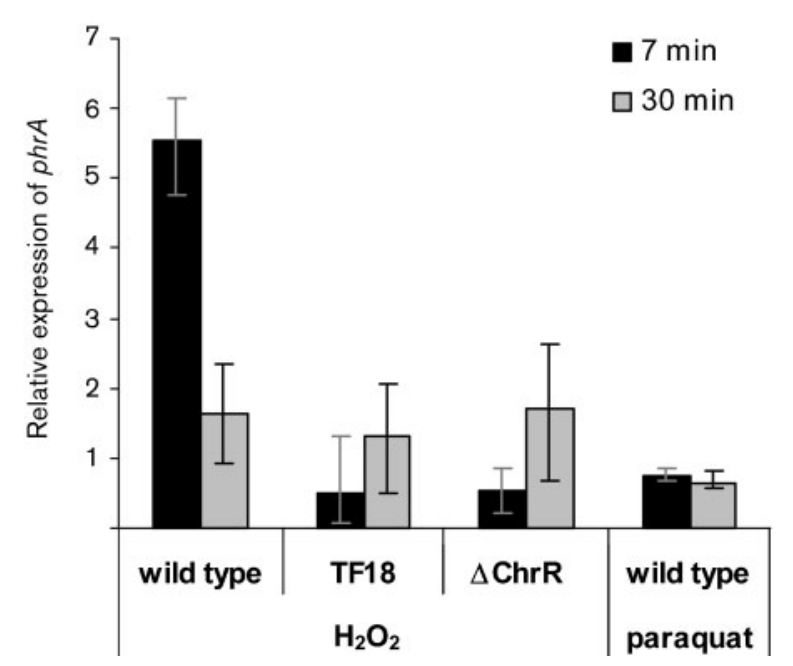

Fig. 4. $\mathrm{H}_{2} \mathrm{O}_{2}$ and paraquat dependent phrA expression in $R$. sphaeroides strains. Cells grown semi-aerobically in the dark to exponential phase were exposed to $1 \mathrm{mM} \mathrm{H}_{2} \mathrm{O}_{2}$ or $1 \mathrm{mM}$ paraquat for 7 and $30 \mathrm{~min}$. phrA transcript levels were determined by realtime RT-PCR. Values represent the relative fold change of phrA expression in treated compared to untreated cells. The mean and maximal deviations of three independent experiments are indicated. 
$\mathrm{H}_{2} \mathrm{O}_{2}$ resulted in a similar $\sim 1.5$-fold increase in phrA transcript levels, we suggest that other factors besides $\sigma^{\mathrm{E}}$ and ChrR are involved in a retarded upregulation of $p h r A$ expression. A fast and transient response is expected, since the $R$. sphaeroides catalases detoxify $\mathrm{H}_{2} \mathrm{O}_{2}$ very quickly (Zeller \& Klug, 2004).

In contrast to $\mathrm{H}_{2} \mathrm{O}_{2}$, paraquat had no significant effect on phrA expression in the wild-type (Fig. 4). Thus, superoxide anions generated by paraquat do not lead to $\sigma^{\mathrm{E}}$ dependent stimulation of phrA.

Anthony et al. (2005) reported that $\sigma^{\mathrm{E}}$ together with its anti- $\sigma$ factor ChrR transmit singlet oxygen dependent signals but are not involved in the response to $\mathrm{H}_{2} \mathrm{O}_{2}$, diamide and superoxide anions. An increase of rpoE expression in the presence of $\mathrm{H}_{2} \mathrm{O}_{2}$ was not observed according to $r p o E$ : lacZ reporter gene studies (Anthony et al., 2005). In contrast to this previous study, we found a significant upregulation of phrA (Fig. 4) and a similar upregulation in rpoE expression (not shown) due to $\mathrm{H}_{2} \mathrm{O}_{2}$ stress using real-time RT-PCR and DNA microarray analysis (Zeller et al., 2005).

In the non-phototrophic $\alpha$-proteobacterium Caulobacter crescentus cadmium sulphate $(6 \mu \mathrm{M})$ caused a sixfold upregulation of the phrA homologue CC1428 ( $\mathrm{Hu}$ et al., 2005). $\mathrm{Cd}^{2+}$ binds to glutathione in Gram-negative bacteria, which subsequently results in the formation of a considerable amount of $\mathrm{H}_{2} \mathrm{O}_{2}$ (reviewed by Nies, 1999). Interestingly, the upstream regions of CC1428 and rpoE/chrR (CCR0645/ CCR0644) encode a putative $R$. sphaeroides $\sigma^{\mathrm{E}}$-dependent promoter sequence. Therefore it is likely that in C. crescentus (i) $\mathrm{H}_{2} \mathrm{O}_{2}$ formation due to $\mathrm{Cd}^{2+}$ stress results in a $\sigma^{\mathrm{E}} / \mathrm{ChrR}$ dependent upregulation of the phrA homologue CCR1428 and (ii) $r p o E$ is transcribed by its own product as suggested for R. sphaeroides (Newman et al., 1999).

\section{$\beta$-Galactosidase-activity in $R$. sphaeroides is affected by $\mathrm{H}_{2} \mathrm{O}_{2}$}

We observed frequently that lac $Z$ reporter assays in $R$. sphaeroides are not suitable to monitor responses to $\mathrm{H}_{2} \mathrm{O}_{2}$ and superoxide anions, indicating sensitivity of the $\beta$ galactosidase enzyme. The data presented in this paper suggest that this might also be the case for singlet oxygen.

We analysed by real-time RT-PCR whether the expression of lac $Z$ in the phrA : lac $Z$ reporter plasmid is enhanced in the wild-type after 7 min incubation with $1 \mathrm{mM} \mathrm{H}_{2} \mathrm{O}_{2}$. We measured a 2.6-fold increase in lacZ-mRNA level (Fig. 5), and a 5.6-fold increase of the mRNA transcribed from the chromosomal copy of phrA (5.6-fold, Figs 4 and 5). When the wild-type harbouring the reporter plasmid was cultured under high intensity white light conditions for $15 \mathrm{~min}$, we observed a 7.4-fold increase of lacZ mRNA level (Fig. 5), which is similar to the increase of phrA mRNA level (Figs $3 c$ and 5).

Based on the result that the lacZ gene expression but not the $\beta$-galactosidase enzymic activity increased, we suggest that this activity is somehow affected by reactive oxygen species. Toptchieva et al. (2003) found that intrinsic tellurite toxicity prevented the use of the lac $Z$ fusion as a reporter for regulatory studies in Proteus mirabilis. Since tellurite oxidizes thiol groups, it contributes to oxidative stress and might affect the $\beta$-galactosidase enzyme in a similar way as ROS.

\section{Conclusion}

Our data reveal that the phrA gene of $R$. sphaeroides encodes a functional photolyase. A response of increased phrA expression caused by light is indeed triggered by singlet oxygen, which is generated by energy transfer from bacteriochlorophyll to molecular oxygen, and the response requires the $\sigma^{\mathrm{E}} / \mathrm{ChrR}$ system. Involvement of photoreceptors or photosynthetic electron transport can be excluded. In contrast to previous studies, we provide evidence that the $\sigma^{\mathrm{E}} / \mathrm{ChrR}$ system is also stimulated by $\mathrm{H}_{2} \mathrm{O}_{2}$. Future investigations will focus on determining by which mechanisms singlet oxygen or $\mathrm{H}_{2} \mathrm{O}_{2}$ affect $\sigma^{\mathrm{E}}$ : ChrR complex dissociation.

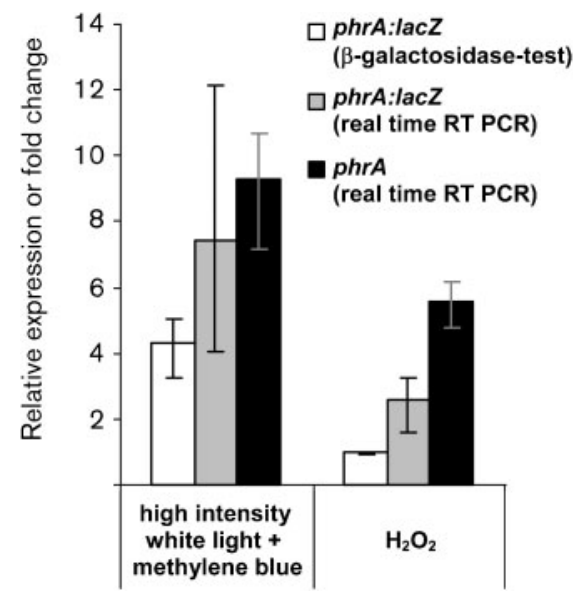

Fig. 5. Comparison of phrA and lac $Z$ expression in $R$. sphaeroides 2.4.1 in response to $\mathrm{H}_{2} \mathrm{O}_{2}$ and high intensity white light irradiation and methylene blue treatment. $\beta$-Galactosidase activity was measured from the phrA : lacZ reporter plasmid. phrA mRNA levels were determined from the gene expressed from chromosomal DNA and lacZ mRNA levels from the phrA : lacZ reporter plasmid in $R$. sphaeroides wild-type. Wild-type cells were grown semiaerobically to exponential phase and exposed to $1 \mathrm{mM} \mathrm{H}_{2} \mathrm{O}_{2}$ for $7 \mathrm{~min}$ for determining expression levels by real-time RT-PCR or $45 \mathrm{~min}$ for $\beta$-galactosidase activity tests. For the generation of singlet oxygen, cells were grown aerobically and treated with high intensity white light and $0.2 \mu \mathrm{M}$ methylene blue for $15 \mathrm{~min}$ to determine mRNA levels by real-time RT-PCR or $120 \mathrm{~min}$ for $\beta$ galactosidase assays. phrA and lac $Z$ expression was normalized to untreated cells. The data represented are the mean of three independent experiments; the $\beta$-galactosidase activity test for $\mathrm{H}_{2} \mathrm{O}_{2}$ dependent expression was done twice. Error bars indicate maximal deviation. 


\section{ACKNOWLEDGEMENTS}

We thank T. Donohue and C. N. Hunter for kindly providing strains and P. Jaschke for critical reading of the manuscript. This work was supported by the Deutsche Forschungsgemeinschaft.

\section{REFERENCES}

Anthony, J. R., Newman, J. D. \& Donohue, T. J. (2004). Interactions between the Rhodobacter sphaeroides ECF sigma factor, $\sigma^{\mathrm{E}}$, and its anti-sigma factor, ChrR. J Mol Biol 341, 345-360.

Anthony, J. R., Warczak, K. L. \& Donohue, T. J. (2005). A transcriptional response to singlet oxygen, a toxic byproduct of photosynthesis. Proc Natl Acad Sci U S A 102, 6502-6507.

Berrocal-Tito, G., Sametz-Baron, L., Eichenberg, K., Horwitz, B. A. \& Herrera-Estrella, A. (1999). Rapid blue light regulation of a Trichoderma harzianum photolyase gene. J Biol Chem 274, 1428814294.

Borland, C. F., McGarvey, D. J., Truscott, T. G., Cogdell, R. J. \& Land, E. J. (1987). Photophysical studies of bacteriochlorophyll $a$ and bacteriopheophytin $a$ - singlet oxygen generation. J Photochem Photobiol B 1, 93-101.

Borland, C. F., Cogdell, R. J., Land, E. J. \& Truscott, T. G. (1989), Bacteriochlorophyll $a$ triplet state and its interactions with bacterial carotenoids and oxygen. J Photochem Photobiol B 3, 237-245.

Braatsch, S. \& Klug, G. (2004). ORF90, a gene required for photoreactivation in Rhodobacter capsulatus SB1003 encodes a cyclobutane pyrimidine dimer photolyase. Photosynth Res 79, 167-177.

Braatsch, S., Gomelsky, M., Kuphal, S. \& Klug, G. (2002). A single flavoprotein, AppA, integrates both redox and light signals in Rhodobacter sphaeroides. Mol Microbiol 45, 827-836.

Braatsch, S., Moskvin, O. V., Klug, G. \& Gomelsky, M. (2004). Responses of the Rhodobacter sphaeroides transcriptome to blue light under semiaerobic conditions. J Bacteriol 186, 7726-7735.

Brudler, R., Hitomi, K., Daiyasu, H., Toh, H., Kucho, K., Ishiura, M., Kanehisa, M., Roberts, V. A., Todo, T. \& other authors (2003). Identification of a new cryptochrome class: structure, function and evolution. Mol Cell 11, 59-67.

Byrdin, M., Eker, A. P., Vos, M. H. \& Brettel, K. (2003). Dissection of the triple tryptophan electron transfer chain in Escherichia coli DNA photolyase: Trp382 is the primary donor in photoactivation. Proc Natl Acad Sci U S A 100, 8676-8681.

Casadaban, M. J., Chou, J. \& Cohen, S. N. (1980). In vitro gene fusions that join an enzymatically active $\beta$-galactosidase segment to amino-terminal fragments of exogenous proteins: Escherichia coli plasmid vectors for the detection and cloning of translational initiation signals. J Bacteriol 143, 971-980.

Cashmore, A. R., Jarillo, J. A., Wu, Y. J. \& Liu, D. (1999), Cryptochromes: blue light receptors for plants and animals. Science 284, 760-765.

Daiyasu, H., Iskikawa, T., Kuma, K., Iwai, S., Todo, T. \& Toh, H. (2004). Identification of cryptochrome DASH from vertebrates. Genes Cells 9, 479-495.

Debus, R. J., Feher, G. \& Okamura, M. Y. (1985). LM complex of reaction centers from Rhodopseudomonas-sphaeroides R-26: characterization and reconstitution with the H-subunit. Biochemistry 24, 2488-2500.

Ditta, G., Schmidhauser, T., Yakobsen, E., Lu, P., Liang, X. W., Finlay, D. R., Guiney, D. \& Helinski, D. R. (1985). Plasmids related to the broad host range vector, pRK290, useful for gene cloning and monitoring gene expression. Plasmid 13, 149-153.
Drews, G. (1983). Mikrobiologisches Praktikum. Heidelberg, Germany: Springer-Verlag.

Fujihashi, M., Numoto, N., Kobayashi, Y., Mizushima, A., Tsujimura, M., Nakamura, A., Kawarabayasi, Y. \& Miki, K. (2007). Crystal structure of archaeal photolyase from Sulfolobus tokodaii with two FAD molecules: implication of a novel light-harvesting cofactor. J Mol Biol 365, 903-910.

Glaeser, J. \& Klug, G. (2005). Photo-oxidative stress in Rhodobacter sphaeroides: protective role of carotenoids and expression of selected genes. Microbiology 151, 1927-1938.

Happ, H. N., Braatsch, S., Broschek, V., Osterloh, L. \& Klug, G. (2005). Light-dependent regulation of photosynthesis genes in Rhodobacter sphaeroides 2.4 .1 is coordinately controlled by photosynthetic electron transport via the PrrBA two-component system and the photoreceptor AppA. Mol Microbiol 58, 903-914.

Hu, P., Brodie, E. L., Suzuki, Y., McAdams, H. H. \& Andersen, G. L. (2005). Whole-genome transcriptional analysis of heavy metal stresses in Caulobacter crescentus. J Bacteriol 187, 8437-8449.

Hübner, P., Willison, J. C., Vignais, P. M. \& Bickle, T. A. (1991). Expression of regulatory nif genes in Rhodobacter capsulatus. J Bacteriol 173, 2993-2999.

Hübner, P., Masepohl, B., Klipp, W. \& Bickle, T. A. (1993). nif gene expression studies in Rhodobacter capsulatus: $n$ trC-independent repression by high ammonium concentrations. Mol Microbiol 10, $123-132$.

Kavakli, I. H. \& Sancar, A. (2004). Analysis of the role of intraprotein electron transfer in photoreactivation by DNA photolyase in vivo. Biochemistry 43, 15103-15110.

Keen, N. T., Tamaki, S., Kobayashi, D. \& Trollinger, D. (1988). Improved broad-host-range plasmids for DNA cloning in gramnegative bacteria. Gene 70, 191-197.

Kihara, J., Moriwaki, A., Matsuo, N., Arase, S. \& Honda, Y. (2004). Cloning, functional characterization, and near-ultraviolet radiationenhanced expression of a photolyase gene (PHR1) from the phytopathogenic fungus Bipolaris oryzae. Curr Genet 46, 37-46.

Klug, G. \& Drews, G. (1984). Construction of a gene bank of Rhodopseudomonas capsulata using a broad host range DNA cloning system. Arch Microbiol 139, 319-325.

Lang, H. P., Cogdell, R. J., Takaichi, S. \& Hunter, C. N. (1995). Complete DNA sequence, specific Tn5 insertion map, and gene assignment of the carotenoid biosynthesis pathway of Rhodobacter sphaeroides. J Bacteriol 177, 2064-2073.

Lin, C. \& Shalitin, D. (2003). Cryptochrome structure and signal transduction. Annu Rev Plant Biol 54, 469-496.

Mitani, H. \& Shima, A. (1995). Induction of cyclobutane pyrimidine dimer photolyase in cultured fish cells by fluorescent light and oxygen stress. Photochem Photobiol 61, 373-377.

Mitani, H., Uchida, N. \& Shima, A. (1996). Induction of cyclobutane pyrimidine dimer photolyase in cultured fish cells by UVA and blue light. Photochem Photobiol 64, 943-948.

Newman, J. D., Falkowski, M. J., Schilke, B. A., Anthony, L. C. \& Donohue, T. J. (1999). The Rhodobacter sphaeroides ECF sigma factor, $\sigma^{\mathrm{E}}$, and the target promoters $c y c \mathrm{~A} \mathrm{P} 3$ and $r p o E \mathrm{P} 1 . J$ Mol Biol 294, 307-320

Newman, J. D., Anthony, J. R. \& Donohue, T. J. (2001). The importance of zinc-binding to the function of Rhodobacter sphaeroides ChrR as an anti-sigma factor. J Mol Biol 313, 485-499.

Nies, D. H. (1999). Microbial heavy-metal resistance. Appl Microbiol Biotechnol 51, 730-750.

Nieuwlandt, D. T., Palmer, J. R., Armbruster, D. T., Kuo, Y.-P., Oda, W. \& Daniels, C. J. (1995). A rapid procedure for the isolation of RNA 
from Haloferax volcanii. In Archaea: A Laboratory Manual, pp. 161162. Edited by F. T. Robb \& A. R. Place. Cold Spring Harbor, NY: Cold Spring Harbor Laboratory Press.

Page, K. A., Connon, S. A. \& Giovannoni, S. J. (2004). Representative freshwater bacterioplankton isolated from Crater Lake, Oregon. Appl Environ Microbiol 70, 6542-6550.

Partch, C. L. \& Sancar, A. (2005). Photochemistry and photobiology of cryptochrome blue-light photopigments: the search for a photocycle. Photochem Photobiol 81, 1291-1304.

Pfaffl, M. W. (2001). A new mathematical model for relative quantification in real-time RT-PCR. Nucleic Acids Res 29, 2002-2007.

Rupert, C. S., Goodgal, S. H. \& Herriott, R. M. (1958). Photoreactivation in vitro of ultraviolet-inactivated Hemophilus influenzae transforming factor. J Gen Physiol 41, 451-471.

Sambrook, J. \& Russell, D. W. (2001). Molecular Cloning: A Laboratory Manual. Cold Spring Harbor, NY: Cold Spring Harbor Laboratory Press.

Sancar, A. (2003). Structure and function of DNA photolyase and cryptochrome blue-light photoreceptors. Chem Rev 103, 2203-2237.

Schilke, B. A. \& Donohue, T. J. (1995). ChrR positively regulates transcription of the Rhodobacter sphaeroides cytochrome $c_{2}$ gene. $J$ Bacteriol 177, 1929-1937.

Selby, C. P. \& Sancar, A. (2006). A cryptochrome/photolyase class of enzymes with single-stranded DNA-specific photolyase activity. Proc Natl Acad Sci U S A 21, 17696-17700.

Simon, R., Priefer, U. \& Pühler, A. (1983). A broad host range mobilization system for in vivo genetic engineering: transposon mutagenesis in gram-negative bacteria. Biotechnology 1, 784-791.

Sockett, R. E., Donohue, T. J., Varga, A. R. \& Kaplan, S. (1989). Control of photosynthetic membrane assembly in Rhodobacter sphaeroides mediated by puhA and flanking sequences. J Bacteriol 171, 436-446.

Tamada, T., Kitadoroko, K., Higuchi, Y., Inaka, K., Yasui, A., de Ruiter, P. E., Eker, A. P. \& Miki, K. (1997). Crystal structure of DNA photolyase from Anacystis nidulans. Nat Struct Biol 4, 887-891.
Tehrani, A., Prince, R. C. \& Beatty, J. T. (2003). Effects of photosynthetic reaction center $\mathrm{H}$ protein domain mutations on photosynthetic properties and reaction center assembly in Rhodobacter sphaeroides. Biochemistry 42, 8919-8928.

Toptchieva, A., Sisson, G., Bryden, L. J., Taylor, D. E. \& Hoffman, P. S. (2003). An inducible tellurite-resistance operon in Proteus mirabilis. Microbiology 149, 1285-1295.

Ueda, T., Kato, A., Kuramitsu, S., Terasawa, H. \& Shimada, I. (2005). Identification and characterization of a second chromophore of DNA photolyase from Thermus thermophilus HB27. J Biol Chem 280, 36237-36243.

van Niel, C. B. (1944). The culture, general physiology, morphology, and classification of the non-sulfur purple and brown bacteria. Bacteriol Rev 8, 1-118.

Vieira, J. \& Messing, J. (1982). The pUC plasmids, an M13mp7derived system for insertion mutagenesis and sequencing with synthetic universal primers. Gene 19, 259-268.

Yang, H. Q., Tang, R. H. \& Cashmore, A. R. (2001). The signaling mechanism of Arabidopsis CRY1 involves direct interaction with COP1. Plant Cell 13, 2573-2587.

Yasuhira, S., Mitani, H. \& Shima, A. (1991). Enhancement of photorepair of ultraviolet-damage by preillumination with fluorescent light in cultured fish cells. Photochem Photobiol 53, 211-215.

Zeilstra-Ryalls, J., Gomelsky, M., Eraso, J. M., Yeliseev, A., O’Gara, J. \& Kaplan, S. (1998). Control of photosystem formation in Rhodobacter sphaeroides. J Bacteriol 180, 2801-2809.

Zeller, T. \& Klug, G. (2004). Detoxification of hydrogen peroxide and expression of catalase genes in Rhodobacter. Microbiology 150, 34513462.

Zeller, T., Moskvin, O. V., Li, K., Klug, G. \& Gomelsky, M. (2005). Transcriptome and physiological responses to hydrogen peroxide of the facultatively phototrophic bacterium Rhodobacter sphaeroides. I Bacteriol 187, 7232-7242.

Edited by: J. Green 